\title{
Global prevalence of putative haemochromatosis mutations
}

\author{
Alison T Merryweather-Clarke, Jennifer J Pointon, Jeremy D Shearman, \\ Kathryn J H Robson
}

\begin{abstract}
Haemochromatosis is a genetic disease associated with progressive iron overload, and is common among populations of northern European origin. HLA-H is a recently reported candidate gene for this condition. Two mutations have been identified, a substitution of cysteine for tyrosine at amino acid 282 (C282Y, nucleotide 845) and of histidine for aspartate at amino acid 63 (H63D, nucleotide 187). Over $90 \%$ of UK haemochromatosis patients are homozygous for the $\mathrm{C282Y}$ mutation. We have examined 5956 chromosomes ( 2978 people) for the presence of HLA-H C282Y and H63D by PCR followed by restriction enzyme analysis. We have found world wide allele frequencies of $1.9 \%$ for $\mathrm{C} 282 \mathrm{Y}$ and $8.1 \%$ for H63D. The highest frequencies were $10 \%$ for $\mathrm{C} 282 \mathrm{Y}$ in 90 Irish chromosomes and $30.4 \%$ for H63D in 56 Basque chromosomes. C282Y was most frequent in northern European populations and absent from 1042 African chromosomes, 484 Asian chromosomes, and 644 Australasian chromosomes. The distribution of the $\mathrm{C} 282 \mathrm{Y}$ mutation coincides with that of populations in which haemochromatosis has been reported and is consistent with the theory of a north European origin for the mutation. The H63D polymorphism is more widely distributed and its connection with haemochromatosis remains unclear. (F Med Genet 1997;34:275-278)
\end{abstract}

MRC Molecular Haematology Unit, Institute of Molecular Medicine, John

Radcliffe Hospital, Headington, Oxford OX3 9DU, UK

A T Merryweather-Clarke J J Pointon

J D Shearman

K J H Robson

Correspondence to: Dr Merryweather-Clarke.

Received 20 November 1996 Revised version accepted for publication 16 January 1997

Keywords: haemochromatosis; HLA-H; north European/Celtic populations.

Haemochromatosis is an autosomal recessive disorder in which increased iron absorption causes iron overload, eventually resulting in undetected. ${ }^{1}$ However, life expectancy is norprecirrhotic stage of the disease. ${ }^{2}$ Patients often do not present until middle age and genetic testing of populations of northern European origin, in which the disease frequency has been estimated at $1 / 300,{ }^{3-7}$ would identify those at risk before the development of tissue damage because of iron overload. Feder et $a l^{\beta}$ have recently identified two mutations in HLA-H, a candidate gene for haemochromatosis on chromosome 6 (6p22.1): a $\mathrm{G}$ to an $\mathrm{A}$ at nucleotide 845 in the codon of amino acid 282, changing cysteine to tyrosine, and a $C$ to a $G$ at nucleotide 187 in the codon of amino acid 63, changing histidine to aspartate. Feder et al found that $83 \%$ of 178 haemochromatosis patients were homozygous for the C282Y mutation. The UK Haemochromatosis Consortium (submitted for publication) has found that over $90 \%$ of 115 UK patients were homozygous for the mutation, with H63D allele frequencies of $2 \%$ in patients and $16 \%$ in controls. Jazwinska et al found that $100 \%$ of 112 Caucasian Australian patients with a positive family history of haemochromatosis were homozygous for the $\mathrm{C} 282 \mathrm{Y}$ mutation, and Beutler $e t a l^{10}$ and Jouanolle $e t a l^{11}$ found that $82.3 \%$ and $92.4 \%$ of Caucasian haemochromatosis patients in the USA and Brittany, respectively, were homozygous for $\mathrm{C} 282 \mathrm{Y}$, and found $\mathrm{H} 63 \mathrm{D}$ allele frequencies of $5.4 \%$ and $3.4 \%$ in patients and $15-16.5 \%$ in controls. Calandro et $a l^{12}$ reported that $80 \%$ of 56 patients in the USA were homozygous for the $\mathrm{C} 282 \mathrm{Y}$ mutation. Therefore, $\mathrm{C} 282 \mathrm{Y}$ is an excellent marker for the disease, whether or not HLA-H is confirmed to be the haemochromatosis gene. What role, if any, H63D plays in haemochromatosis remains to be established.

We have analysed 5956 chromosomes for these mutations, in order to ascertain the relationship between their prevalence and that of

the disease in populations with different frequencies of haemochromatosis. tissue damage which can be fatal if mal if iron is removed by venesection in the

\section{Methods}

The origin of DNA samples is shown in the footnotes to table 1 . All populations screened were anonymous to the authors. The two regions of the HLA-H gene containing the proposed mutations were amplified by $\mathrm{PCR}^{8}$ before restriction fragment length polymorphism (RFLP) analysis. For both PCR products, primers were designed to include an internal restriction enzyme site in the product, to act as a control for complete digestion. Both 
PCR reactions were performed using an annealing temperature of $58^{\circ} \mathrm{C}$.

For the H63D mutation, the following primers gave a product of 294 bp: H63DF: 5' ACA TGG TTA AGG CCT GTT GC; H63DR: 5' CTT GCT GTG GTT GTG ATT TTC C. Following digestion with $M b o I$, those products carrying the mutation gave restriction fragments of 237 and $57 \mathrm{bp}$, while fragments lacking the mutation contained an extra $\mathrm{MboI}$ site and gave restriction fragments of 138,99 , and $57 \mathrm{bp}$.

For the C282Y mutation, the following primers gave a product of $343 \mathrm{bp}$ : C282YF: 5' CAA GTG CCT CCT TTG GTG AAG GTG ACA CAT; C282YR: 5' CTC AGG CAC TCC TCT CAA CC. Following digestion with RsaI, those fragments containing the mutation carried an additional $R s a \mathrm{I}$ site, resulting in products of 203, 111, and $29 \mathrm{bp}$, whereas those

Table 1 Genotype frequencies for mutations in $H L A-H$

\begin{tabular}{|c|c|c|c|c|c|c|c|c|c|}
\hline Population & Total No & $H H / C C$ & $H D / C C$ & $D D / C C$ & $H H / C Y$ & $H D / C Y$ & $H H / Y Y$ & $\begin{array}{l}\text { H63D allele frequency } \\
(\%, \pm 95 \% C I)\end{array}$ & $\begin{array}{l}\text { C282Y allele frequency } \\
(\%, \pm 95 \% \text { CI })\end{array}$ \\
\hline \multicolumn{10}{|l|}{ Europe } \\
\hline \multicolumn{10}{|l|}{ British } \\
\hline${ }^{\star} \mathrm{UK}$ & 368 & 249 & 77 & 0 & 28 & 12 & 2 & $12.1( \pm 2.4)$ & $6.0( \pm 1.8)$ \\
\hline †Irish & 45 & 23 & 13 & 0 & 5 & 4 & 0 & $18.9( \pm 8.3)$ & $10( \pm 6.3)$ \\
\hline Total British & 413 & 272 & 90 & 0 & 33 & 16 & 2 & $12.8( \pm 2.3)$ & $6.4( \pm 1.7)$ \\
\hline$\ddagger$ Icelanders & 90 & 63 & 14 & 1 & 9 & 3 & 0 & $10.6( \pm 4.6)$ & $6.7( \pm 3.7)$ \\
\hline$\ddagger$ Norwegians & 94 & 63 & 17 & 2 & 12 & 0 & 0 & $11.2( \pm 4.6)$ & $6.4( \pm 3.6)$ \\
\hline \multicolumn{10}{|l|}{ Former USSR } \\
\hline †Mekhelta Highlands & 63 & 50 & 10 & 1 & 2 & 0 & 0 & $9.5( \pm 5.2)$ & $1.6( \pm 2.2)$ \\
\hline †Mekhelta Lowlands & 45 & 38 & 6 & 0 & 1 & 0 & 0 & $6.7( \pm 5.3)$ & $1.1( \pm 2.2)$ \\
\hline Total Mekhelta & 108 & 88 & 16 & 1 & 3 & 0 & 0 & $8.3( \pm 3.8)$ & $1.4( \pm 1.6)$ \\
\hline fUdmurts & 46 & 33 & 12 & 1 & 0 & 0 & 0 & $15.2( \pm 7.5)$ & $0(+3.2)$ \\
\hline Total Former USSR & 154 & 121 & 28 & 2 & 3 & 0 & 0 & $10.4( \pm 3.5)$ & $1.0( \pm 1.1)$ \\
\hline †Finns & 38 & 29 & 9 & 0 & 0 & 0 & 0 & $11.8( \pm 7.4)$ & $0(+3.8)$ \\
\hline †Danes & 37 & 23 & 6 & 1 & 6 & 1 & 0 & $12.2( \pm 7.6)$ & $9.5( \pm 6.8)$ \\
\hline †Netherlanders & 39 & 17 & 18 & 2 & 1 & 1 & 0 & $29.5( \pm 10.3)$ & $2.6( \pm 3.6)$ \\
\hline †Germans & 53 & 36 & 11 & 4 & 1 & 1 & 0 & $18.9( \pm 7.6)$ & $1.9( \pm 2.7)$ \\
\hline †Bavarians & 62 & 41 & 14 & 0 & 7 & 0 & 0 & $11.3( \pm 5.7)$ & $5.6( \pm 4.1)$ \\
\hline Total Germans & 115 & 77 & 25 & 4 & 8 & 1 & 0 & $14.8( \pm 4.7)$ & $3.9( \pm 2.6)$ \\
\hline †Ashkenazi Jews & 35 & 29 & 6 & 0 & 0 & 0 & 0 & $8.6( \pm 8.4)$ & $0(+4.1)$ \\
\hline \| Italians & 91 & 69 & 19 & 2 & 1 & 0 & 0 & $12.6( \pm 4.9)$ & $0.5( \pm 1.0)$ \\
\hline t\$Greeks & 139 & 105 & 25 & 4 & 5 & 0 & 0 & $11.9( \pm 3.9)$ & $1.4( \pm 1.4)$ \\
\hline SGreek Cypriots & 57 & 39 & 16 & 2 & 0 & 0 & 0 & $17.5( \pm 7.1)$ & $0(+2.6)$ \\
\hline Total Greeks & 196 & 144 & 41 & 6 & 5 & 0 & 0 & $13.5( \pm 3.5)$ & $1.3( \pm 1.1)$ \\
\hline †Turks & 31 & 21 & 9 & 1 & 0 & 0 & 0 & $17.7( \pm 9.7)$ & $0(+4.6)$ \\
\hline §Turkish Cypriots & 39 & 32 & 6 & 1 & 0 & 0 & 0 & $10.3( \pm 6.9)$ & $0(+3.7)$ \\
\hline Total Turks & 70 & 53 & 15 & 2 & 0 & 0 & 0 & $13.6( \pm 5.8)$ & $0(+2.1)$ \\
\hline \multicolumn{10}{|l|}{ Spanish } \\
\hline †Basques & 28 & 14 & 7 & 5 & 2 & 0 & 0 & $30.4( \pm 12.3)$ & $3.6( \pm 5.0)$ \\
\hline †Catalans & 50 & 27 & 18 & 2 & 1 & 2 & 0 & $24.0( \pm 8.5)$ & $3.0( \pm 3.4)$ \\
\hline Total Spanish & 78 & 41 & 25 & 7 & 3 & 2 & 0 & $26.3( \pm 7.0)$ & $3.2( \pm 2.8)$ \\
\hline Total Europe & 1450 & 1001 & 313 & 29 & 81 & 24 & 2 & $13.6( \pm 1.3)$ & $3.8( \pm 0.7)$ \\
\hline \multicolumn{10}{|l|}{ Africa/Middle East } \\
\hline || Saudi Arabians & 118 & 98 & 20 & 0 & 0 & 0 & 0 & $8.5( \pm 3.6)$ & $0(+1.3)$ \\
\hline Gambians & 39 & 38 & 1 & 0 & 0 & 0 & 0 & $1.3( \pm 2.6)$ & $0(+3.7)$ \\
\hline †Senegalese & 130 & 130 & 0 & 0 & 0 & 0 & 0 & $0(+1.1)$ & $0(+1.1)$ \\
\hline || Kenyans & 78 & 76 & 2 & 0 & 0 & 0 & 0 & $1.3( \pm 1.8)$ & $0(+1.9)$ \\
\hline †Nigerians & 80 & 77 & 3 & 0 & 0 & 0 & 0 & $1.9( \pm 2.2)$ & $0(+1.8)$ \\
\hline$\star \star$ Zambians & 76 & 75 & 1 & 0 & 0 & 0 & 0 & $0.7( \pm 1.4)$ & $0(+1.9)$ \\
\hline \multirow{2}{*}{\multicolumn{10}{|c|}{ Indian subcontinent }} \\
\hline & & & & & & & & & \\
\hline §Sri Lankans & 109 & 90 & 18 & 1 & 0 & 0 & 0 & $9.2( \pm 3.9)$ & $0(+1.4)$ \\
\hline \Indians/Pakistanis & 106 & 89 & 16 & 0 & 1 & 0 & 0 & $7.5( \pm 3.6)$ & $0.5( \pm 1.0)$ \\
\hline Total Indian subcontinent & 215 & 179 & 34 & 1 & 1 & 0 & 0 & $8.4( \pm 2.7)$ & $0.2( \pm 0.4)$ \\
\hline \multicolumn{10}{|l|}{ Asia } \\
\hline t\$Hong Kong Chinese & 72 & 68 & 4 & 0 & 0 & 0 & 0 & $2.8( \pm 2.7)$ & $0(+2.0)$ \\
\hline †Taiwanese Aboriginals & 80 & 80 & 0 & 0 & 0 & 0 & 0 & $0(+1.8)$ & $0(+1.8)$ \\
\hline †Indonesians & 90 & 85 & 5 & 0 & 0 & 0 & 0 & $2.8( \pm 2.5)$ & $0(+1.6)$ \\
\hline Total Asia & 242 & 233 & 9 & 0 & 0 & 0 & 0 & $1.9( \pm 1.2)$ & $0(+0.6)$ \\
\hline \multicolumn{10}{|l|}{ Australasia } \\
\hline \multicolumn{10}{|l|}{ Papua New Guineans } \\
\hline ๆHighlands & 41 & 41 & 0 & 0 & 0 & 0 & 0 & $0(+3.5)$ & $0(+3.5)$ \\
\hline qLowlands & 98 & 98 & 0 & 0 & 0 & 0 & 0 & $0(+1.5)$ & $0(+1.5)$ \\
\hline Total Papua New Guinea & 139 & 139 & 0 & 0 & 0 & 0 & 0 & $0(+1.1)$ & $0(+1.1)$ \\
\hline$†$ Australian Aboriginals & 93 & 93 & 0 & 0 & 0 & 0 & 0 & $0(+1.6)$ & $0(+1.6)$ \\
\hline$\|$ Vanuatuans & 90 & 89 & 1 & 0 & 0 & 0 & 0 & $0.6( \pm 1.2)$ & $0(+1.6)$ \\
\hline Total Australasia & 322 & 321 & 1 & 0 & 0 & 0 & 0 & $0.2( \pm 0.9)$ & $0(+0.5)$ \\
\hline \multicolumn{10}{|l|}{ Americas } \\
\hline †Mexicans & 54 & 47 & 7 & 0 & 0 & 0 & 0 & $6.5( \pm 4.7)$ & $0(2.7)$ \\
\hline || Jamaicans & 90 & 84 & 4 & 0 & 2 & 0 & 0 & $2.2( \pm 2.2)$ & $1.1( \pm 1.6)$ \\
\hline fColumbians & 47 & 47 & 0 & 0 & 0 & 0 & 0 & $0(+3.1)$ & $0(+3.1)$ \\
\hline †Vancouver Island Indians & 37 & 35 & 1 & 0 & 1 & 0 & 0 & $1.4( \pm 2.7)$ & $1.4( \pm 2.7)$ \\
\hline Total Americas & 228 & 213 & 12 & 0 & 3 & 0 & 0 & $2.6( \pm 1.5)$ & $0.7( \pm 0.8)$ \\
\hline Total & 2978 & 2441 & 396 & 30 & 85 & 24 & 2 & $8.1( \pm 0.7)$ & $1.9( \pm 0.4)$ \\
\hline
\end{tabular}

H63D allele frequencies significantly greater in Europe than in Africa/Middle East ( $<<0.0001$ ), Indian subcontinent ( $p=0.0025$ ), Asia ( $<<0.0001$ ), Australasia $(\mathrm{p}<0.0001)$, and Americas $(\mathrm{p}<0.0001)\left(\chi^{2}\right.$ test $)$.

C282Y frequencies significantly greater in Europe than in in Africa/Middle East $(p<0.0001)$, Indian subcontinent ( $p<0.0001$ ), Asia ( $<<0.0001$ ), Australasia $(p<0.0001)$, and Americas $(p=0.0006)\left(\chi^{2}\right.$ test $)$.

Origins of samples: ${ }^{\star}=$ family studies of collagen disorders and polycystic kidney disease; $t=$ anthropological community based surveys; $\neq=$ blood donors; $\delta=$ referrals for diagnosis of haemoglobinopathies; $\|=$ community based surveys of haemoglobinopathies; $\|=$ community based malarial survey; $\star \star=$ neonatal survey of haemoglobinopathies.

Genotypes are given for amino acid $63(\mathrm{H} 63 \mathrm{D}) /$ amino acid $282(\mathrm{C} 282 \mathrm{Y})$ of the polypeptide $(\mathrm{C}=$ cysteine, $\mathrm{D}=$ aspartic acid, $\mathrm{H}=\mathrm{histidine}, \mathrm{Y}=$ tyrosine $)$. CC/HH is normal (wild type). The combinations $\mathrm{DD} / \mathrm{CY}, \mathrm{DD} / \mathrm{YY}$, and $\mathrm{HD} / \mathrm{YY}$ were not found. 
lacking the mutation yielded products of 203 and $140 \mathrm{bp}$.

Ninety-five percent confidence intervals were calculated assuming a binomial distribution, and $\chi^{2}$ analysis was performed using Statview 4.1 (Abacus Concepts Inc, Berkeley, CA, USA).

\section{Results}

Results are shown in table 1. A total of 2900 European chromosomes was analysed and the $\mathrm{C} 282 \mathrm{Y}$ and $\mathrm{H} 63 \mathrm{D}$ mutations were observed at frequencies of $3.8 \%$ and $13.6 \%$, respectively.

The H63D mutation was present in all European populations included in the study, at allele frequencies greater than $6 \%$, and in Saudi Arabian, Indian Asian, and Mexican populations at $8.5 \%, 8.4 \%$, and $6.5 \%$ respectively. It was present at lower frequencies in Africans, Asians, and native Americans, and was not found in Colombians, most Australasians (except a single Vanuatuan), Taiwanese Aboriginals, or Senegalese.

The C282Y mutation was found in all European populations studied except Udmurts, Ashkenazi Jews, Finns, Greek Cypriots, and Turkish Cypriots, and, with the exception of one Indian heterozygote and two Jamaican heterozygotes, was absent from all other populations. The highest allele frequencies were found in the UK (6.4\% overall, including $10 \%$ in Irish chromosomes), Danes (9.6\%), Icelanders $(6.7 \%)$, Norwegians $(6.4 \%)$, and Bavarians $(5.6 \%)$.

\section{Discussion}

Feder et al suggested that the H63D mutation increases the risk of haemochromatosis for $\mathrm{C} 282 \mathrm{Y}$ heterozygotes, and that compound heterozygotes have a low penetrance iron storage disease. The UK Haemochromatosis Consortium (submitted for publication) found that three of 115 patients were compound heterozygotes suffering from mild disease, and four of 101 control subjects were compound heterozygotes who showed no signs of iron loading. In the present study, we have found a frequency of compound heterozygotes in the UK, Denmark, Iceland, and the Netherlands of approximately $1 / 30$, which is much higher than previous estimates of haemochromatosis frequency. Therefore, if enhanced risk of disease exists for this genotype, our data support the hypothesis that it is low penetrance. An alternative explanation of the variation in the phenotype of compound heterozygotes is that the $\mathrm{H} 63 \mathrm{D}$ polymorphism may be associated with more than one haplotype, only one of which carries a second mutation causing haemochromatosis. We have found high H63D frequencies in populations not previously reported to suffer from haemochromatosis. This finding sheds doubt on the significance of the mutation in this disease, and indicates that it is unlikely to be implicated independently of another mutation.

The C282Y mutation was most prevalent in north European populations, and absent from 3056 non-European chromosomes studied except for three chromosomes (one Indian and two Jamaican). These results strongly suggest that the mutation originated in northern Europe, which is where haemochromatosis is generally accepted to have arisen. Simon et $a l^{1314}$ have postulated that the geographical distribution of haemochromatosis is similar to the migration pattern of Celtic peoples, and Smith et $a l^{15}$ concluded that there was a significantly higher prevalence of haemochromatosis in Americans of British/Irish descent compared with that of Americans of other Caucasian descent. The distribution of the C282Y mutation is therefore similar to that of haemochromatosis. The presence of the allele in Indian and Jamaican populations at trace levels may be because of admixture with Europeans in the history of these peoples.

The high percentage of C282Y heterozygotes found in north European populations indicates homozygote frequencies of $1 / 100$ in Ireland, $1 / 278$ in the rest of the UK (we found $2 / 368=1 / 184), 1 / 111$ in Denmark, $1 / 223$ in Iceland, and 1/244 in Norway. A previous estimate of the haemochromatosis frequency in Denmark is $1 / 217-1 / 270,{ }^{7}$ considerably lower than our extrapolated frequency of $1 / 111$. This discrepancy may have arisen because of the small sample number of 37 Danes included in the present study, or may indicate that a large number of Danish haemochromatotics are undiagnosed. A haemochromatosis frequency of $1 / 270$ indicates an allele frequency of $6.1 \%$, which is within our $95 \%$ confidence limits.

These observed allele frequencies are comparable with previous estimates of haemochromatosis frequencies in populations of north European origin of $1 / 200-1 / 300$ in predominantly Caucasian Australians, ${ }^{6}$ French Bretons, ${ }^{3}$ Swedes (Jutlanders), ${ }^{4}$ and North Americans. ${ }^{5}$ Low frequencies have previously been observed in Finns, ${ }^{16}$ who are known to differ genetically from other north European populations, ${ }^{17}$ and our findings are consistent with this.

Haemochromatosis has not been confirmed in those populations lacking the $\mathrm{C} 282 \mathrm{Y}$ mutation. There have been isolated reports of nonchromosome 6 linked iron overload in a Chinese woman, ${ }^{18}$ in a Melanesian kindred, ${ }^{19}$ and many accounts of African siderosis. ${ }^{20-24}$ This condition was first recognised in the Bantu tribe of southern Africa. Bantu siderosis may be distinguished from haemochromatosis in that the levels of iron deposited in the liver and bone marrow are comparable in siderosis, but in haemochromatosis, the liver is the major site of iron storage. ${ }^{23}$ An additional example of non-chromosome 6 linked hyperferritinaemia with normal serum iron has recently been described in overweight French subjects. ${ }^{25}$ There have also been reports of a hereditary hyperferritinaemia in France and Italy which is associated with a congenital cataract condition, in which raised serum ferritin is not related to iron overload. ${ }^{26}{ }^{27}$ It is important not to confuse haemochromatosis with other iron overload disorders. In 1965, a world study of haemochromatosis distribution concluded that the highest incidence of haemochromatosis occurred in Africans of the Bantu tribe, while the 
lowest frequencies were observed among the English and Scandinavians. ${ }^{28}$ However, with the benefit of 30 years of research, notably the discovery of linkage to the MHC region on chromosome $6(6 \mathrm{p} 21.3)^{29}$ and the identification of a candidate gene, ${ }^{8}$ it is now clear that the converse is true.

Other conditions and mutations for which a Celtic or North European origin has been implicated are described in references 30-38. Asthma affects $1 / 7$ children in the UK, and a genome screen has recently established linkage to the marker D6S276, ${ }^{39} 2 \mathrm{Mb}$ from HLA-H on chromosome $6(6 \mathrm{p} 22.1)$. It is conceivable that an HLA mutation may be involved in asthma, and given the high frequency of H63D in north European populations, the possibility of such an association should not be ignored.

We have identified several northern European populations in which there is a high incidence of the C282Y mutation, an excellent marker for the haemochromatosis gene. We suggest that it is now important to initiate a genetic screening programme followed by measurements of transferrin saturation and hepatic iron index in homozygotes, to confirm the nature and severity of the disease, and to implement therapeutic phlebotomy where appropriate. This approach is financially advantageous ${ }^{40}$ and will be a major advance in preventative health care.

This work was partially supported by the EC (contract No BMH4-CT96-0994). JDS was a Wellcome Research Trainin Fellow. We thank the following for providing DNA samples: $H$ Ayyub, Professor J Bertranpetit, Dr K Bulayeva, Professor J Clegg, C Fisher, V Gamble, Dr P Harris, Professor D Higgs, Professor A V S Hill, C Irvine, Dr J Martinson, Dr J M Old, Dr D Rees, Dr A Sofro, Dr B Sykes, Dr D Undlien, and Professo $\mathrm{R}$ Ward. We are also grateful to the following for interesting discussion: Professor J Clegg, Dr R Harding, Y T Liu, Dr V Macaulay, Dr J Martinson, Dr D Rees, and Dr W Riu, Dr Finally, Finally, we thank Professor Sir
support and encouragement.

1 Bothwell TH, Charlton RW, Motulsky AG. Hemochromatosis. In: Scriver CR, Beaudet AL, Sly WS, eds. The molecular basis of inherited disease. New York: McGraw-Hill, basis of inherice

2 Niederau C, Fischer R, Purschel A, Stremmel W, Haussinger D, Strohmeyer G. Long-term survival in patients with inger D, Strohmeyer G. Long-term survival in patients with hereditary

3 Beaumont C, Simon M, Fauchet R, et al. Serum ferritin as a possible marker of the haemochromatosis allele. $N$ Engl $\mathcal{F}$ Med 1979;301:169-74.

4 Olssen KS, Ritter B, Rosen U, Heedman PA, Staugard F. Prevalence of iron overload in central Sweden. Acta Med Scand 1983;213:145-50.

5 Edwards CQ, Griffen LM, Goldgar D, Drummond C, Skolnick $\mathrm{MH}$, Kushner JP. Prevalence of hemochromatosis among 11,065 presumably healthy blood donors. $N$ Engl $\mathcal{F}$ Med 1988;318:1355-62.

6 Leggett BA, Halliday JW, Brown NN, Bryant S, Powell LW. Prevalence of haemochromatosis amongst asymptomatic Australians. Br ₹ Haematol 1990;74:525-30.

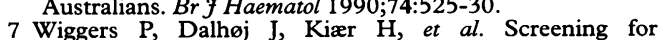
Wiggers P, Dalhøj J, Kiær H, et al. Screening for haemochromatosis: prevalence amo

8 Feder JN, Gnirke A, Thomas W, et al. A novel MHC class I-like gene is mutated in patients with hereditary haemochromatosis. Nat Genet 1996;13:399-409.

9 Jazwinska EC, Cullen LM, Busfield F, et al. Scientific correspondence. Nat Genet 1996;14:249-51.

10 Beutler E, Gelbart T, West C, et al. Mutation analysis in hereditary haemochromatosis. Blood Cells Mol Dis 1996;22 187-94.

11 Jouanolle AM, Gandon G, Jezequel P, et al. Scientific correspondence. Nat Genet 1996;14:251-2.

12 Calandro L, Thorsen T, Barcellos L, Griggs J, Baer D, Sensabaugh GF. Mutation analysis in hereditary haemochromatosis - commentary. Blood Cells Mol Dis 1996;22:194AB.
13 Simon M, Alexandre JL, Fauchet R, Genetet B, Bourel M. The genetics of hemochromatosis. In: Steinberg AG, Bearn AG, Motulsky AG, Childs B, eds. Progress in medical genetics. Philadelphia: W B Saunders, 1980.

14 Simon M, LeMignon L, Fauchet R, et al. A study of 609 HLA haplotypes marking for the hemochromatosis gene: (1) mapping of the gene near the HLA locus and characters required to define a heterozygous population and (2) hypothesis concerning the underlying cause of hypothesis concerning the underlying cause of hemochromatosis-

15 Smith BN, Kantrowitz W, Grace ND, et al. Is British-Irish ancestry a risk factor for genetic hemochromatosis? International association for the study of disorders of iron metabolism, Boston, 1995:A33:75.

16 Karlsson M, Ikkala E, Reunanen A. Prevalence of hemochromatosis in Finland. Acta Med Scand 1988;224: 385-90.

17 Cavalli-Sforza LL, Piazza A. Human genomic diversity in Europe: a summary of recent research and prospects for the future. Eur f Hum Genet 1993;1:3-18.

18 Oliver M, Scully L, Guiraudon C, Adams PC. Non-HLAlinked hemochromatosis in a Chinese woman. Dig Dis $\mathrm{Sci}$ 1995;40:1589-91.

19 Eason RJ, Aston CE, Adams PC, Searle J. Familial iron overload with possible autosomal dominant inheritance. Aust NZ F Med 1990;29:226-30.

20 Bothwell TH, Abrahams C, Bradlow BA, Charlton RW. Idiopathic and Bantu hemochromatosis - comparative histological study. Arch Pathol 1965;79:163-8.

21 Gordeuk V, Mukiibi J, Hasstedt SJ, et al. Iron overload in Africa: interaction between a gene and dietary iron content. N Engl f Med 1992;326:95-100.

22 Barton JC, Edwards CQ, Bertoli LF, Shroyer TW, Hudson SL. Iron overload in African Americans. $A m \mathcal{F}$ Med 1995;99:616-23.

23 Baer D. Hereditary iron overload and African Americans. Am $\mathcal{f}$ Med 1996;100:5-8.

24 Wurapa RK, Gordeuk VR, Brittenham GM, Khiyami A, Schechter GP, Edwards CQ. Primary iron overload in African Americans. Am 7 Med 1996;101:9-18.

25 Moirand R, Mortaji AM, Loréal O, Paillard F, Brissot P, Deugnier Y. A new syndrome of liver iron overload with normal transferrin saturation. Lancet 1997;349:95-7.

26 Beaumont C, Leneuve P, Devaux I, et al. Mutation in the iron responsive element of the $L$ ferritin $m R N A$ in a family with dominat hyperferritinaemia and cataract. Nat Genet 1995;11:444-6.

27 Girelli D; Corrocher R, Bisceglia L, et al. Molecular basis for the recently described hereditary hyperferritinemiacataract syndrome: a mutation in the iron-responsive cataract syndrome: a mutation in the iron-responsive tion"). Blood 1995;86:4050-3.

28 MacDonald RA. Hemochromatosis and cirrhosis in different geographic areas. Am F Med Sci 1965;249:36-46.

29 Simon M, Pawlotsky Y, Bourel M, Fauchet R, Genetet B. Hémochromatose idiopathique. Maladie associée à l'antigène tissulaire HL-A3? Nouv Presse Med 1975;4:1432.

30 Treacy E, Byck S, Clow C, Scriver CR. "Celtic" phenylketonuria chromosomes found? Evidence in two regions of Quebec Province. Eur $\mathcal{F}$ Hum Genet 1993;1:220-8.

$31 \mathrm{Hu}$ FL, Gu Z, Kozich V, Kraus JP, Ramesh V, Shih VE. Molecular basis of cystathionine $\beta$-synthase deficiency in pyroxidone responsive and nonresponsive homocystinuria. Hum Mol Genet 1993;2:1857-60.

32 Long CC, Marks R. Increased risk of skin cancer: another Celtic myth? A review of Celtic ancestry and other risk factors for malignant and nonmelanoma skin cancer. $f \mathrm{Am}$ Acad Dermatol 1995;33:658-61.

33 Martinson JJ, Chapman NH, Rees DC, Liu YT, Clegg JB. Global distribution of the $C C R-5$ gene 32 basepair deletion. Nat Genet (in press)

34 Cox DW, Woo SLC, Mansfield T. DNA restriction fragments associated with $\alpha 1$-antitrypsin indicate a single origin for deficiency allele PI $Z$. Nature $1985 ; 316: 79-81$.

35 The Cystic Fibrosis Genetic Analysis Consortium. Population variation of common cystic fibrosis mutations. Hum Mutat 1994;4:167-77.

36 Morral N, Bertranpetit J, Estivill X, et al. The origin of the major cystic fibrosis mutation $(\Delta \mathrm{F} 508)$ in European populations. Nat Genet 1994;7:169-75.

37 Sawcer S, Jones HB, Feakes R, et al. A genome screen in multiple sclerosis reveals susceptibility loci on chromosome 6p21 and 17q22. Nat Genet 1996;13:464-8.

38 The Multiple Sclerosis Genetics Group, represented by Haines JL, et al. A complete genomic screen for multiple sclerosis underscores a role for the major histocompatability complex. Nat Genet 1996;13:469-71.

39 Daniels SE, Bhattacharya S, James A, et al. A genome-wide search for quantitative trait loci underlying asthma. Nature 1996; 383:247-50

40 Adams PC, Gregor JC, Kertesz AE, Valberg LS. Screening blood donors for hereditary hemochromatosis: decision analysis model based on a 30-year database. Gastroenterology 1995;109:177-88. 